\title{
The Case For The Prairie Dog
}

\section{by J. David Chandler and Ruth Chandler, Masefield}

In the case of the prainie dog there are many for, and few against ... but the voices raised against him are by far the loudest and most frequently heard.

On October 15th we were fortunate enough to tune into a CBC program which presented the case for various birds and animals which have the hand of man against them. Dr. R. Nero spoke in the cause of the prairie dog. His eloquence was not emotional, he drew a picture both vivid and poetic. We felt again the wild, untouched atmosphere which seems to prevail wherever prairie dogs colonize a town. Heard again the wistful, inquiring bark. Felt again the revulsion which came over us when we saw for ourselves the massacre being indiscriminately carried out.

The ranchers are actually bitter in their denunciation when the matter is brought up. It is true that we who are pulling for this gregarious little prairie nomad have nothing to losebut it is also possible that poor management of grazing land is a causative factor in the recent increase in number.

It is unlikely that any of us would protest control. In the September issue of the Blue Jay, a survey report on the prairie dog by the Department of Natural Resources was printed. Mr. Paynter pointed out that one dog town was in a game preserve and therefore protected. His report, too, was inclined to range public sympathy on the side of the rancher. However, some of us would be poorly pleased to see one colony preserved and the remainder (if possible) wiped out.

We would like to see a proposal raised to protect the rehabilitated prairie dogs of the original dog town. This is settled on land which is naturally arid and sparsely grassed, land belonging to Ed Purask, who was quoted as being quite unperturbed by the presence of prairie dogs. It might be assumed that this dog town is as popular with visiting naturalists as any other. It was here that Dalton Muir spent a week filming the dogs for the National Film Board. Here our "own" naturalist, Ralph Stueck, made his capture of a dozen or more for the requirements of some zoo. Here Ken Campibell filmed and recorded for the Educational Film Board.

The town is settled on an attractive site. The approach is over hilly terrain, suddenly stretching out in a broad flat benching the river. To the west the "Three Sisters" stand forever sentinel. If one has the patience to lie low on some nearby promontory one can watch, with the aid of binoculars, the amusing antics of the dogs in everyday life. At the approach of anything foreign to the colony, numerous little dogs pop up from their circular mounded holes like a finger poked up through the center of a doughnut, busily sounding their quaint, staccato barks of curiosity and defiance. When grazing, one dog may run to another a few feet distant, "kiss" and return to grazing. Or, (as noted by more serious observers) if rebuffed or ignored, the

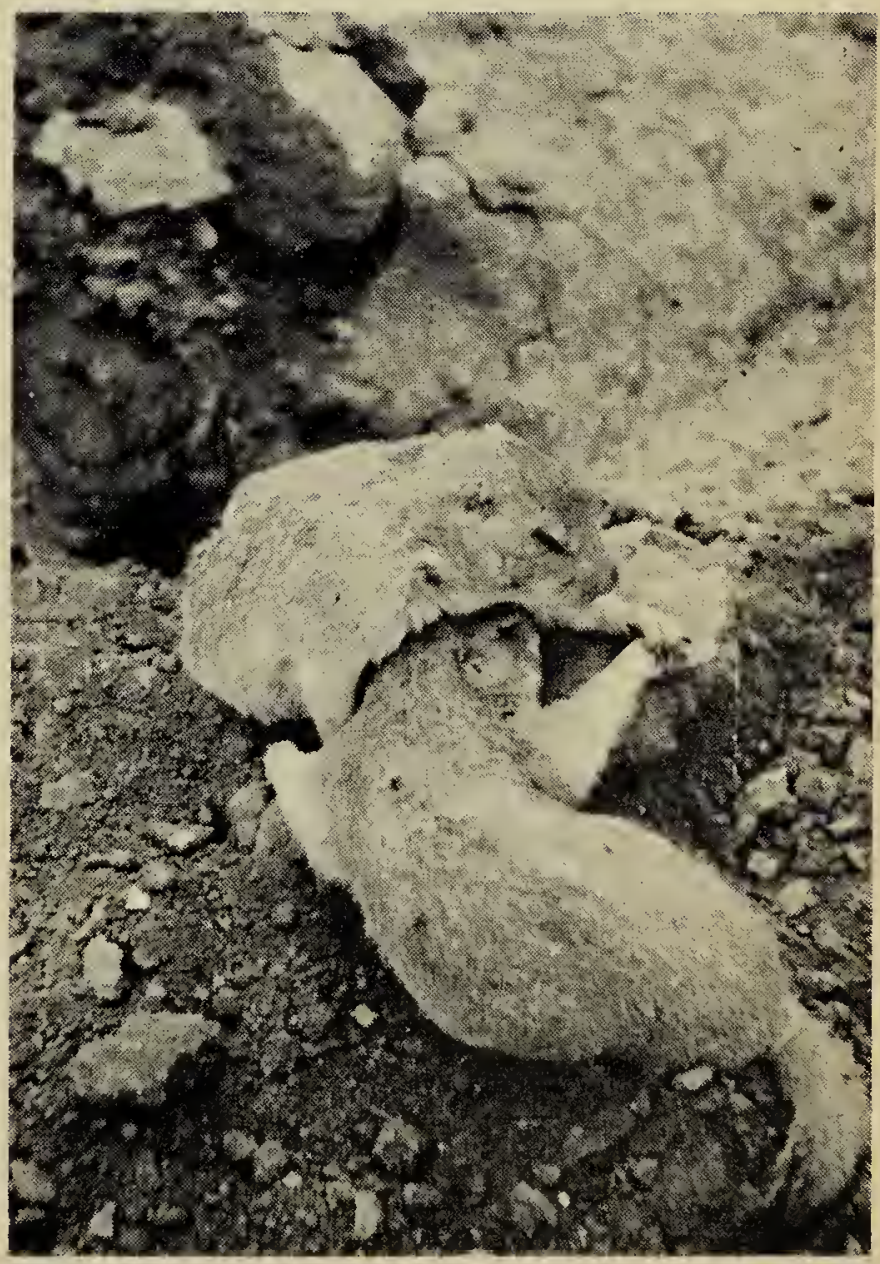

Prairie Dogs, June, 1962 
one making the advance may raise its tail, spread it, snarl-and then either a kiss is forthcoming, or a chase is on.

Regarding the suggestion that overgrazing encourages the increase of prairie dogs, we would like to quote Ronald E. Smith in his Natural History report of the Prairie Dogs of Kansas, University of Kansas, Museum of Natural History and State Biology Survey.

". . Since the study by Taylor, Vorhies and Lister on jackrabbits in 1935 , the concept of "animal weeds" set forth by them has been accepted by most ecologists. The concept is that certain animals, like certain plants, increase with the disturbance of the climax and decline as the climax is restored. Data in numerous papers have substantiated the concept but it seems not to be fully understood by many farmers and ranchers, who could make the most use of it.

"Even the farmer-rancher group accepts the fact that rabbits and various range rodents are more numerous on depleted and weedy ranges than on ranges of good vegetative cover, but alniost without exception wrongly regards these mammals as the "cause" instead of the "result" of range depletion by overgrazing. Taylor, Vorhies and Lister set up protected plots next to plots heavily grazed by livestock and separated only by a barbed wire stock fence. Grazing pressure from jackrabbits was three times as heavy on the plot grazed by cattle as on the protected plot.

"At the Wichita Mountains, Wildlife Refuge in Oklahoma, Osborn and Allan recorded an instance where a prairie dog colony was protected and cattle removed from the area. In spite of the activities of the prairie dogs, the grass cover increased in density and the prairie dogs abandoned the area because it reverted to vegetation unsuitable as a habitat for them."

Some Lady Lake Shrew RecordsOn August 26, 1962, I trapped a water shrew (Sorex palustris) in a bit of marsh bordering the Lilian River near Lady Lake (six miles north of Preeceville in eastern Saskatchewan). The closest record to my knowledge is at Hudson Bay (Blue Jay, 17: 125) about 60 miles north. The expected range of the water shrew is across the forested region of Saskatchewan (and Canada) in suitable habitat, but definite locality records are desirable for this and other species.

This brings the number of shrew species taken in the Lady Lake area to five. I've caught the Arctic shrew (Sorex arcticus) (one specimen, August 14, 1961; another, July 25, 1962), a pygmy shrew (Microsorex hoyi) (one, June 27, 1962) in the same marsh, and a short-tailed shrew (Blarina brevicauda) (one, August 23,1961 ) on an island in a nearby lake. The masked shrew (Sorex cinereus) is the common species; I've taken a number of specimens.Donald J. Buckle, Lady Lake.

Red fox and possible mountain lion at Shaunavon-The March and June issues of the Blue Jay (1962) carried reports of the red fox being seen in the extreme southwestern part of Saskatchewan. I am pleased to note the interest evinced and, for myself, I hope that the fox continues to increase and move southward-which it appears to be doing. I drove out to Jim Stevenson's place, five miles northwest of Shaunavon, after hearing a report of a red fox having been dug out on his farm in May. On the way out a fox crossed the road just ahead of the car, paying scant attention to my approach. According to the boys, the den was about 12 feet long and four feet deep. They found seven pups, which they gave to some interested person; later, however, the young foxes made their escape to freedom. It is believed that there was a second den in the near vicinity.

There were also reports of a mountain lion being sighted seven miles northeast of Shaunavon as it passed within 50 yards of an oil drilling rig. It was very dark, about 1:00 a.m., and when a spotlight was turned on, the animal took off. Further rumors have it that it was later roaming the Pine Creek Park, 18 miles southwest of Shaunavon.-J. David Chandler, Masefield.

Please report any mountain lion observations to $T$. White, 3-1919 Scarth Street, Regina. 